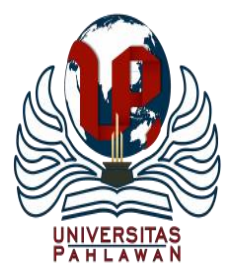

Edukatif : Jurnal Ilmu Pendidikan Volume 3 Nomor 4 Tahun 2021 Halm 1460 - 1469

EDUKATIF: JURNAL ILMU PENDIDIKAN

Research \& Learning in Education

https://edukatif.org/index.php/edukatif/index

\title{
Analisis Fenomena Pembelajaran Daring Pada Masa Pandemi (Harapan Menuju Blended Learning)
}

\author{
Kutsiyyah \\ Institut Agama Islam Negeri (IAIN) Madura, Indonesia \\ E-mail : kutsiyah812@gmail.com
}

\begin{abstract}
Abstrak
Artikel ini membahas tentang pembelajaran daring yang menjadi fenomena di Indonesia sejak pandemi covid19. Penelitian ini bertujuan menganalisis pembelajaran daring yang terjadi selama masa pandemi, meliputi media yang banyak digunakan dalam proses pembelajaran, ciri pembelajaran daring berikut kelebihan dan kendala yang dihadapi di lapangan. Kajian ini berupa studi literatur yang dikenal juga dengan library research. Untuk menemukan kesimpulan dalam kajian ini, penulis menggunakan model Miles and Huberman dalam mengalisis data yaitu melalui empat tahapan analisis meliputi data collecting (pengumpulan data), data reduction (reduksi data), data display (penyajian data), dan conclusion drawing/verification (penarikan kesimpulan dan verifikasi). Hasil dari penelitian ini menunjukkan bahwa semua jenjang pendidikan menerapkan pembelajaran daring selama pandemi. Mulai jenjang sekolah dasar hingga perguruan tinggi, media yang banyak digunakan yaitu aplikasi whatsapp (WA). Kemudahan, kepraktisan serta pilihan fitur yang cukup membantu adalah alasan utama aplikasi WA menjadi pilihan favorit sebagai media dalam pembelajaran daring. Pembelajaran daring memiliki empat ciri umum, yaitu Personal, Structured, Active dan Connective. Masing-masing ciri ini memiliki kelebihan dan kelemahan tersendiri sehingga juga membutuhkan kretivitas guru.
\end{abstract}

Kata Kunci: Pembelajaran daring, pandemi, blended learning.

\section{Abstract}

This article discusses online learning which has become a phenomenon in Indonesia since the COVID-19 pandemic. This study aims to analyze online learning that occurred during the pandemic, includes media that used in the learning process, the characteristics of online learning and also the advantages and constraints faced in the field. This study is a literature study which is also known as library research. To find conclusions in this study, the author uses the Miles and Huberman model in analyzing the data that is data collecting, data reduction, data display, dan conclusion drawing/verification. The results of this study indicate that all levels of education use online learning during the pandemic. Starting from elementary school to college level, the media that is widely used is the WhatsApp (WA) application. The Ease, practicality and features of WA application that helpful are the main reasons why this application being a favorite choice as a medium for online learning. Online learning has four general characteristics: Personal, Structured, Active and Connective. Each of these characteristics has its own advantages and disadvantages so it also requires teacher creativity.

Keywords: online learning, pandemic, blended learning.

Copyright (c) 2021 Kutsiyyah

$\triangle$ Corresponding author
Email $\quad$ kutsiyah812@gmail.com
DOI $\quad:$ https://doi.org/10.31004/edukatif.v3i4.580


1461 Analisis Fenomena Pembelajaran Daring Pada Masa Pandemi (Harapan Menuju Blended Learning) Kutsiyyah

DOI: https://doi.org/10.31004/edukatif.v3i4.580

\section{PENDAHULUAN}

Pandemi yang diakibatkan covid-19 pada awal tahun 2020 kemarin melanda berbagai negara di dunia. Virus ini berdampak pada berbagai sektor kehidupan dalam masayarakat meliputi ekonomi, pendidikan, pariwisata dan aktivitas-aktivitas lain yang harus terhenti untuk menghidari dan mengurangi penyebaran. Berbagai kebijakan baru juga dibuat oleh pemerintah dalam upaya menanggulaninya dan membentuk kebiasaan-kebiasan baru dengan menerapkan protokol kesehatan (Rahmadi, n.d.). Sebagai akibat dari terhentinya dan dibatasinya berbagai aktivitas di berbagai sektor, memaksa banyak orang untuk lebih kreatif dalam memanfaatkan yang ada bahkan menciptakan hal baru untuk tetap bisa melaksanakan tugas dan kewajiban serta kebutuhan-kebutuhan lain yang tidak bisa ditinggalkan.

Hal yang paling nyata sebagai dampak pandemi di dunia pendidikan ini yakni kebingungan para pendidik dalam menerapkan kegiatan belajar mengajar di tengah-tengah keterbatasan gerak dan sarana. Kebijakan pemerintah untuk mengurangi penyebaran covid-19 ini salah satunya meniadakan Ujian Nasional (UN) tahun 2020 dan tatap muka dalam kegiatan pembelajaran dengan mengeluarkan Surat Edaran Nomor 4 Tahun 2020 tentang Pelaksanaan Pendidikan Dalam Masa Darurat Coronavirus Disease (Covid-19) (Mendikbud RI, 2020). Seluruh masyarakat dianjurkan kerja dari rumah, belajar dari rumah dan beribadah di rumah. Maka dari itu, kegiatan pembelajaran dilakukan secara online atau dalam jaringan (daring). Para pendidik mulai membuka kembali berbagai metode alternatif yang bisa digunakan dalam masa-masa daring ini. Tentu hal ini tidaklah mudah, mengingat proses ini dilakukan dalam waktu cepat dan harus dilakukan.

Metode pembelajaran merupakan implementasi dari rencana yang ada pada strategi pembelajaran. Maka dengan metode yang dipilih dalam pembelajaran diharapkan bisa mencapai tujuan pembelajaran seefesien dan seefektif mungkin. Dalam tatap muka, metode-metode lebih mudah dilaksanakan dalam proses pembelajaran. Ruang, waktu serta kebersamaan siswa dan guru bisa ada dalam satu waktu kegiatan belajar mengajar. Siswa akan lebih mudah bertanya, mengemukakan pendapat, berinteraksi dengan nyata serta memperoleh role model yang bisa memberi makna dan nilai-nilai pendidikan.

Metode bisa diartikan sebagai suatu cara yang dipilih pendidik atau dipergunakan dalam megimplementasikan rencana yang telah disusun dalam suatu kegiatan nyata untuk mencapai tujuan pembelajaran yang optimal. Dalam tulisannya, Lavasani \& Faryadres tentang saran strategi dan model dalam belajar menjelaskan bahwa pelajar dengan strategi yang bervariasi dan tidak akan tampak perbedaanya, "Also best learners employed more and a greater variety of strategies than the poorer ones" (Lavasani \& Faryadres, 2011). Dari ungkapan ini dapat dipahami bahwa tidak ada satupun strategi yang lebih baik dari lainnya. Maka harus memilih yang paling efektif dan butuh variasi. Begitupun dengan metode tidak ada yang lebih baik dari lainnya (Kutsiyyah, 2019). Bisa jadi dalam satu proses pembelajaran terdapat beberapa metode yang digunakan untuk mencapai tujuan yang direncanakan.

Dalam masa pandemi ini, guru dan berbagai kalangan lainnya yang terlibat dalam dunia pendidikan mencari haluan baru dalam mencapai tujuan pembelajaran yang sudah direncanakan sebelum masa-masa belajar dari rumah. Tren media online tentu merupakan alternatif dalam pelaksanaan pembelajaran pada masa pandemi. Meski terdapat media online khususnya penggunaan sosial media yang sudah akrab dengan masyarakat, tidak menjamin pelaksanaan daring bisa berjalan dengan mulus. Berbagai hambatan juga sering muncul dalam pelaksanaan proses pembelajaran. Dan ini kembali mendorong guru untuk terus berinovasi dengan berbagai pilihan alternatif agar proses pembelajaran terus berlangsung. Pembelajaran daring ini memang berperan besar dan bermanfaat dalam terlaksananya proses pembelajaran dan layanan pendidikan selama masa pandemi yakni sesuai tujuan dua surat edaran Kemendikbud di atas. Namun, juga tidak dipungkiri terdapat banyak kekurangan yang perlu dibenahi agar cita-cita pendidikan sesuai harapan.

Saat pembelajaran online/daring, semua kegiatan pembelajaran harus mulai menyesuaikan dengan keadaan pandemi. Untuk mendukung kegiatan pembelajaran selama di rumah pemerintah juga menerbitkan 
1462 Analisis Fenomena Pembelajaran Daring Pada Masa Pandemi (Harapan Menuju Blended Learning) Kutsiyyah

DOI: https://doi.org/10.31004/edukatif.v3i4.580

pedoman pengelenggaraan belajar dari rumah (BDR) melalui Surat Edaran Nomor 15 Tahun 2020 sehingga memperkuat surat edaran sebelumnya tentang pelaksanaan pembelajaran pada masa covid-19. Oleh karena itu, aktivitas dan penugasan saat belajar di rumah bisa bervariasi sesuai dengan kondisi, minat dan fasilitas yang ada di daerah masing-masing (Kemdikbud, 2020). Dengan demikian proses belajar mengajar akan tetap bisa dilaksanakan meski dari rumah masing-masing. Tujuan pembelajaran diharapkan bisa tercapai dan siswa tetap mendapatkan layanan pendidikan.

Namun demikian, ketidaksiapan sarana, sklill, waktu dan biaya merupakan hambatan-hambatan yang umum dijumpai sehingga banyak dari pembelajaran daring ini menjadi sulit untuk mengontrol siswa dan mengukur ketercapaian tujuan pembelajaran. Ada beberapa penelitian terdahulu yang menunjukkan kendalakendala tersebut, seperti yang terjadi pada wali murid sekolah Muhammadiyah yang menghadapi beberapa problem selama mendampingi belajar secara daring yakni kesulitan dalam mendapingi anak belajar, banyaknya beban belajar anak sehingga sulit memahami materi, terkendala kuota dan jaringan internet serta keterbatasan media. Selain yang disebutkan masih terdapat pula kendala dalam skala kecil seperti kondisi rumah dan lingkungan yang kurang mendukung (Istikomah et al., 2020). Yang demikian juga terjadi dalam pembelajaran tingkat anak usia dini pada masa pandemi, seperti sarana dan prasarana, kurangnya pemahaman, ketidaksiapan guru dan orangtua bahkan penilaian juga menjadi problem dalam hal ini (Harahap et al., 2021). Tidak menutup kenyataan bahwa di tingkat pendidikan tinggi juga mengalami kendala serupa sehingga perkuliahan tidak berjalan maksimal dan motivasi belajar menurun (Khasanah et al., 2020). Dalam kaitannya dengan pandemi yang melanda, sistem ini sudah membantu meminimalisir penyebaran covid-19 (Nina Nurmila, Maslani, Tarsono, 2020), namun berbagai problema proses pendidikan di atas menjadi perhatian besar untuk bisa segera diatasi.

Oleh karena itu, belajar dari rumah ini perlu dilakukan kajian lebih dalam khususnya terkait pembelajaran daring dengan menganalisis yang terjadi selama masa pandemi, meliputi media apa yang banyak digunakan dalam proses pembelajaran, ciri pembelajaran daring berikut kelebihan dan kendala yang dihadapi di lapangan. Sehingga hasilnya bisa dijadikan bahan acuan untuk pembelajaran daring kedepannya yang lebih baik dan optimal.

\section{METODE PENELITIAN}

Penelitian ini betujuan menganalisis pemebelajaran daring yang terjadi selama masa pandemi, meliputi media yang banyak digunakan dalam proses pembelajaran, ciri pembelajaran daring berikut kelebihan dan kendala yang dihadapi dalam pelaksanaannya. Adapun metode yang digunakan ialah kajian literatur yang dikenal juga dengan. Kajian literatur ini merujuk pada kajian teoritis dan referensi lain yang berhubungan dengan nilai, sosial budaya dan norma yang berkembang pada situasi sosial yang diteliti. Karena itu penelitian jenis ini akan mengumpulkan dan mengkaji dari literatur-literatur ilmiah (Sugiyono, 2019).

Setelah ditentukan topik terkait penelitian, penulis mengumpulkan data yang sesuai untuk dikaji dalam penelitian ini baik berupa jurnal penelitian nasional maupun internasional, kebijakan pemerintah terkait pembelajaran di rumah pada masa pandemi, artikel, surat kabar serta literartur lainnya yang menunjang. Oleh karena itu, teknis analisis data yang digunakan yakni secara kualitatif dengan model Miles and Huberman (Sugiyono, 2019) yaitu melalui empat tahapan analisis. Pertama data collecting (pengumpulan data) yakni mencari data berupa literatur baik jurnal penelitian, peraturan pemerintah tentang proses pembelajaran masa pandemi, artikel dan surat kabar. Kedua data reduction (reduksi data) yakni merangkum, memilih hal-hal yang pokok dan penting dari data yang diperoleh. Tahap ketiga data display (penyajian data) yaitu dalam library research ini bentuk penyajian data dibuat dengan membuat uraian dalam teks yang bersifat naratif. Terakhir tahap keempat adalah conclusion drawing/verification (penarikan kesimpulan dan verifikasi) yaitu setelah memilih data-data penting dari literatur terkait topik yang diteliti dan menarasikan dalam bentuk 
1463 Analisis Fenomena Pembelajaran Daring Pada Masa Pandemi (Harapan Menuju Blended Learning) Kutsiyyah

DOI: https://doi.org/10.31004/edukatif.v3i4.580

deskriptif, maka berikutnya adalah mengambil kesimpulan. Di tahap ini akan tergambar rumusan masalah atau temuan dari penelitian tentang analisis pembelajaran daring selama pandemi.

\section{HASIL DAN PEMBAHASAN PENELITIAN}

\section{Fenomena Pembelajaran Daring Di Semua Jenjang Pendidikan}

Sebelum pandemi covid-19 ini terjadi, pembelajaran online/daring sudah ada dan beberapa sudah menerapkan dengan menggunakan beberapa platform pembelajaran daring yang berbasis pada penggunaan internet. Di Indonesia jarang ditemukan pembelajaran daring dan masih menggunakan pembelajaran konvensional yakni dalam bentuk tatap muka langsung dengan sistem klasikal sebagaimana diketahui bersama.

Online learning (pembelajaran daring) adalah bentuk dari pembelajaran jarak jauh yakni guru dan siswa tidak ada dalam ruang yang sama sehingga guru menggunakan media untuk transfer ilmu. Awal mula pembelajaran daring dikenal yaitu sebagai pengaruh dari perkembangan pembelajaran berbasis elektronik $(e-$ learning) yang diperkenalkan oleh Universitas Illionis melalui sistem pembelajaran berbasis komputer (Hardiayanto). Pembelajaran daring merupakan suatu sistem pembelajaran yang dapat memfasilitasi siswa belajar lebih luas, lebih banyak, dan bervariasi. Konten atau materi yang ada dalam fasilitas tersebut mampu memberikan siswa pilihan yang bervariasi yakni tidak hanya dalam bentuk werbal, melainkan bisa dilengkapi dengan audio, visual dan gerak. Tentu ini akan menjadi daya Tarik tersendiri bagi siswa sehingga membantu dalam memahami pesan yang disampaikan. Karena sistem ini berbasis internet, maka juga mampu diakses kapan dan dimana saja sehingga pembelajaran juga semakin fleksibel (Riyana, 2015). Maka demikian dapat dipahami bahwa secara umum pembelajaran daring sangat berbeda dengan pembelajaran konvemsional atau tatap muka langsung. Dalam pembelajaran daring membutuhkan kemandirian siswa dalam belajar dan mengolah informasi dari materi yang diberikan secara daring.

Setahun terakhir ini sudah banyak dilakukan pembelajaran daring di sekolah-sekolah bahkan kampuskampus di seluruh Indonesia. Walaupun fenomena ini terjadi sebagai dampak dari pandemi, tahap demi tahap masyarakat mulai mengakrabkan diri dengan pembelajaran daring. Sebagai langkah sederhana, pembelajaran daring dimulai dengan memanfaatkan media sosial yang ada, familiar dan mudah digunakan seperti whatsapp (WA), telegram dan youtube. Tidak sedikit juga masyarakat menggunakan aplikasi yang memang dibuat untuk proses pembelajaran seperti google classroom, Edmodo, google meet atau zoom.

Seperti yang terjadi di Provinsi Lampung, pembelajaran daring juga dilaksanakan dengan akses internet. Berdasar data yang diperoleh dari penelitian tersebut, berikut beberapa media atau aplikasi yang banyak digunakan dalam pembelajaran daring selama pandemi covid-19 di Provinsi Lampung. Sebanyak $87,2 \%$ proses pembelajaranan menggunakan Whatsapp, sedangkan penggunaan Google Classroom sebanyak 41.3\%, Youtube 15,6 \%, Google Meeting atau Zoom sebanyak 13, 8\%, dan aplikasi lainnya 12,8\%. Dari data tersebut dapat dibaca bahwa penggunaan aplikasi Whatsapp menduduki tempat pertama yakni paling banyak digunakan dalam pelaksanaan pembelajaran daring. Dalam keterangan yang diperoleh dijelaskan bahwa penggunan whatsapp sebagai pilihan utama dalam pembelajaran daring yaitu karena kepraktisan dan kemudahan dalam menggunakannya baik di oleh siswa maupun guru. Hal itu juga karena aplikasi yang dibuat untuk media komunikasi ini, sudah menjadi media umum dan familier di masyarakat. Meski Whasapp bukan dirancang untuk media pembelajaran, namun dengan fitur yang disediakan seperti kemampuan mengirim pesan, foto, video, link, maupun melampirkan tugas-tugas pembelajaran sudah sangat membantu dalam terlaksananya proses pembelajaran jarak jauh / daring pada masa pandemi (Kristina et al., 2020).

Dalam penelitian yang dilakukan di beberapa lembaga pendidikan juga menunjukkan banyak sekolah yang menggunakan media social whatsapp dalam pelaksanaan proses pembelajaran sejak merebaknya covid19 di tanah air dan diperkuat dengan terbitnya peraturan pemerintah tentang belajar dari rumah sejak Maret 
1464 Analisis Fenomena Pembelajaran Daring Pada Masa Pandemi (Harapan Menuju Blended Learning) Kutsiyyah

DOI: https://doi.org/10.31004/edukatif.v3i4.580

2020. Sebagaimana dalam sebuah penelitian yang dilakukan pada kelas III C di SD Negeri 027 Samarinda Ulu. Proses pembelajaran yang berbasis pada penggunakan handphone ini menjadikan media WA untuk melaksakan pembelajaran. Hal ini juga dikarenakan penggunaannya yang mudah dan familiar. WA sebagai aplikasi yang umum digunakan oleh masyarakat menjadikan guru memilih aplikasi tersebut untuk memanfaatkan dalam kondisi yang terdesak ini (Ding et al., 2020). Alasan mendasarnya tidak jauh berbeda dengan penelitian yang sebelumnya, yakni kemudahan dan kepraktisan aplikasi tersebut dengan beberapa layanan fiturnya.

Pada saat ini media WA memang banyak membantu dalam pelaksanaan belajar dari rumah. Ini terjadi hampir di semua jenjang Pendidikan baik tingkah sekolah maupun perguruan tinggi. Sebagaimana disebutkan sebelumnya bahwa fitur-fitur tersebut menyediakan penyampaian pesan perorangan, penyampaian pesan dalam grup, melampirkan video, melampirkan foto, melampirkan file dalam bentuk pdf ataupun word, panggilan suara dan video conference bahkan mengirimkan pesan suara dan WA yang relatif lebih murah jika dibandingkan aplikasi yang lain. Kegiatan pembelajaran yang dilakukan guru kimia SMA Negeri 15 Semarang ini menyatakan bahwa ternyata setelah dievaluasi, pembelajaran daring menggunakan WA juga bersifat efektif. Hal ini bisa terlihat dari peserta didik yang memberi respon tanggapan dalam jangka waktu yang tidak lama, bagitu pula saat mereka mengerjakan dan mengumpulkan tugasnya. Dengan kata lain, mayoritas peserta didik mengumpulkan tugas tepat waktu. Aka tetapi kelemahan yang bisa terjadi dengan menggunakan media WA ini yaitu menyebabkan kapasitas penyimpanan handphone cepat penuh, sehingga kinerja hp akan melambat. Sebagai alternatif, maka guru menggunakan media lain untuk mengurangi kelemahan tersebut dengan menggunakan google classroom atau email untuk mengumpulkan tugas-tugasnya (Tasropi, 2020).

Dari temuan-temuan di atas fenomena whatsapp (WA) sebagai media yang diminati siswa menunjukkan bahwa kemudahan dan kepraktisannya sebagai tolak ukur mereka memilik aplikasi tersebut. Tidak hanya itu, bahkan di tingkat perguruan tinggi banyak yang menggunakannya. Berikut beberapa penelitian yang dilakukan di beberapa perguruan tinggi pada masa pandemi terkait proses pelaksanaan sistem perkuliahannya yang juga menghasilkan temuan positif. Penelitian yang dilakukan oleh Abidah terkait penggunaan WA sebagai media pembelajaran pada perkuliahan metodologi penelitian selama perkuliahan tersebut berlangsung melalui observasi dan angket, menunjukkan respon positif serta memberi manfaat dalam keberlangsungan proses perkuliahan selama masa pandemi. Temuan ini dibuktikan dengan $94.17 \%$ mahasiswa yang menjawab bahwa aplikasi pintar ini sangat membantu sebagai sarana komunikasi dalam kegiatan perkuliahan. Selain itu, responden yang terlibat dalam pelaksanaan kuliah ini dengan menggunakan WA juga menyampaikan bahwa ruang diskusi menjadi lebih luas dan tidak terikat ruang maupun waktu. Melalui WA, meningkatkan kemampuan mahasiswa secara mandiri dan aktif dalam belajar (Abidah, 2020).

Sebelum pandemi covid-19 melanda, penggunaan WA dalam proses pembelajaran juga pernah dilakukan. Hasilnya bahkan $100 \%$ mahasiswa menanggapi positif dan terbantu dalam proses pembelajaran dengan menggunaka WA. Hasil ini diperoleh dari penelitian dalam perkuliahan Penilaian Pendidikan Fisika dengan sistim blended learning yang menggunakan WA sebagai sarana komunikasi, diskusi, dan bertukar pikiran. Tiga puluh dua responden yang terlibat dalam penelitian tersebut merupakan calon guru fisika di jurusan fisika FMIPA UM pada tahun 2017. Hasil wawancara, observasi serta angket yang diberikan menunjukkan respon baik yakni pembelajaran menjadi lebih menarik, mahasiswa lebih aktif dalam nerdiskusi baik saat daring maupun luring (Khusaini et al., 2017). Dari penelitian ini, maka besar kemungkinan hal yang terjadi ketika blended learning dengan menggunakan WA sebagai salah satu medianya, juga akan memberi respon yang baik juga. Tentu hal ini jika pandemi ini berakhir dan bisa melaksanakan blended learning.

Aplikasi WA yang sangat praktis ini dan mudah dalam pengoperasiannya menjadi pilihan favorit sebagai alternatif media dalam pembelajaran daring. Pilihan fitur yang cukup baik untuk mendukung proses pembelajaran memberikan banyak manmaaf bagi guru, dosen dan peserta disik maupun mahasiswa. memori 
1465 Analisis Fenomena Pembelajaran Daring Pada Masa Pandemi (Harapan Menuju Blended Learning) Kutsiyyah

DOI: https://doi.org/10.31004/edukatif.v3i4.580

yang dibutuhkan pun cukup ringan di HP. sehingga kendala-kendala yang ada dalam pembelajaran daring seddikit terkurangi meski tidak semuanya. Namun, dalam hal ini sebagaimana hasil-hasil penelitian di atas sudah menampakkan hasil dan manfaat yang besar selama belajar dari rumah pada masa-masa pandemi.

\section{Ciri Umum Pembelajaran Daring Serta Kelebihan Dan Kendalanya}

Dari fenomena pembelajaran online atau dalam jaringan yang sekarang dikenal dengan pembelajaran daring, selama masa pandemi bukan hal yang asing lagi. Sangat dimungkinkan juga, kebiasaan baru ini dalam dunia pendidikan akan berlanjut. Paling tidak dengan adanya blended learning, kegiatan pembelajaran secara daring bisa terus dilakukan melihat banyaknya manfaat atau hal positif yang bisa dirasakan. Hal-hal yang tidak bisa dijangkau dengan daring, bisa terus dilakukan dengan pembelajaran tatap muka atau konvensional. Kedua model ini tentu akan bisa saling melengkapi.

Terdapat beberapa ciri pembelajaran daring secara umum yang disampaikan oleh para ahli. Inti ciri umum ini diambil dari beberapa teori dan pendekatan terkait pembelajaran daring. Akan tetapi secara garis besar menurut Flinders University, yaitu Personal, Structured, Active dan Connective. Berikut penjelasannya (Riyana, 2015):

1. Pembelajaran Individu. Dalam pembelajaran daring siswa menciptakan sendiri pengalaman belajarnya. Siswa dituntut untuk mandiri secara pribadi dalam mengikuti pembelajaran. Sistem daring ini juga bisa meminimalisir waktu yakni tidak perlu melakukan perjalanan ke sekolah atau kampus dan menyiapkan banyak hal untuk berangkat ke sekolah. Mereka bisa melakukan dimana dan kapan saja saat belajar. Pembelajaran daring ini benar-benar dilakukan atas diri sendiri karena tidak harus terikat dengan ruang dan waktu tertentu. Siswa juga bisa mengambil atau menciptakan suasana yang diinginkan sehingga bisa belajar dengan nyaman. Karena siswa harus belajar secara sendiri dan mandiri, selain bisa menciptakan suasana belajar sesuai keinginan namun sebagaimana disebut di atas, ada kalanya juga membuat siswa lalai atau tidak bisa melakukan pembelajaran karena merasa sendiri atau lainnya.

Terdapat beberapa faktor yang bisa mempengaruhi keberhasilan pembelajaran daring yang dilakukan oleh siswa/peserta didik baik internal atau pun eksternal. Faktor internal yang dapat mempengaruhi yaitu kecerdasan masing-masing siswa, rasa ingin tahu siswa yang tinggi, motivasi belajar dan kepribadian siswa. Sedangkan faktor eksternal yang dapat mempengaruhi pembelajaran daring yaitu teknologi yang dipakai, lingkungan sekitar dan kecepatan akses internet. faktor-faktor ini sudah banyak terbukti di lapangan sebagaimana hasil penelitian terhadap tanggapan guru tentang pembelajaran daring, di antaranya guru menyampaikan bahwa siswa sulit memahami materi dan tugasnya, kuota yang menghabiskan banyak biaya, dan lain sebagainya (Anggianita et al., 2020). Hal serupa juga tampak pada pembelajaran daring di Lampung, yaitu siswa tidak jarang menemukan kendala dan kesulitan dalam pembelajaran daring seperti jaringan internet yang tidak stabil, tugas yang diberikan cukup banyak mengingat para guru meminta siswa belajar mandiri di rumah, sulit fokus serta aplikasi yang rumit (Kristina et al., 2020).

Oleh karena itu, agar bisa mengontrol diri selama proses pembelajaran berlangsung maka perlu menciptakan kehadiran guru. Maka dalam pembelajaran daring perlu peran guru juga ada, misal dengan menggunakan teknologi atau aplikasi kuis, media interaktif dan sejenisnya sehingga siswa meskipun dengan belajar sendiri tetap bisa mengontrol diri untuk terus melangkah belajar secara mandiri dan memenuhi target yang harus dicapai.

2. Terstruktur dan Sistematis. Pembelajaran daring bisa jadi lebih fleksibel, namun tugas guru atau pendidik tetap harus dipenuhi agar tujuan tetap bisa tercapai bahkan bisa melampaui harapan. Salah satu tugasnya yaitu merencakan pembelajaran. Dengan perencanaan yang matang, maka proses dan tujuan pembelajaran akan mudah dicapai. Hal yang paling sederhana dilakukan yakni pembuatan silabus dan Rencana Pelaksanaan Pembelajaran (RPP). Semua proses pembelajaran harus dilakukan secara teratur, 
1466 Analisis Fenomena Pembelajaran Daring Pada Masa Pandemi (Harapan Menuju Blended Learning) Kutsiyyah

DOI: https://doi.org/10.31004/edukatif.v3i4.580

terstruktur dan sistematis baik menyangkut media, sumber, strategi bahkan dari tujuan, kompetensi yang harus dicapai, langkah-langkah kegiatan hingga evaluasi pembelajaran. Dengan demikian, tugas-tugas ini sama persis denngan pembelajaran tatap muka. Maka kreatifitas dan inovasi guru sangat diperlukan dalam hal ini.

3. Mengutamakan Keaktifan Siswa. Baik dalam pemebelajaran tatap muka (konvensional) maupun daring, keaktifan siswa harus terlibat sehingga proses pembelajaran terasa hidup. Pada saat pembelajaran daring/online, untuk menciptakan keaktifan siswa terkadang ada kendala tersendiri, bisa disebabkan oleh media yang digunakan, kuota/sinyal internet atau dari individu. Sebagai salah satu contoh tidak memberi kesempatan atau menyediakan forum diskusi untuk menanyakan materi yang dipelajari. Meskipun ada, tidak sedikit siswa yang mengabaikan kesempatan tersebut. Sebab lainnya yang banyak dijumpai juga yaitu beberapa siswa hanya mengisi daftar hadir dan tidak aktif lagi hingga proses pembelajaran selesai (Asmuni, 2020). Solusi ketidakaktifan siswa ini bisa dengan stimulus agar motivasi belajarnya tetap ada. Oleh karena itu dengan media pembelajaran yang menarik sesuai dengan karakteristik siswa khususnya sekolah dasar dan karekteristik era revolusi industri 4.0, multimedia interaktif seperti macromedia flash 8 bisa digunakan dan dikirim melalui WA atau link selama belajar di rumah (Wahyugi \& Fatmariza, 2021). Kendala-kendala seperti ini juga bisa lebih mudah teratasi jika media atau aplikasi yang digunakan on camera yang dikenal juga dengan synchronous, menyertakan konten yang menarik sehingga menarik perhatian siswa, komunikasi yang aktif dari guru selama proses pembelajaran atau bisa juga dengan kuis daring. Ini didukung dengan hasil sebuah penelitian yang membandingkan penggunaan media synchronous dan asynchronous menunjukkan perbedaan signifikan. Tingkat kefektifan terjadi pada metode synchronous dengan menggunakan video conference. Maka hal ini juga berdampak pada hasil belajar siswa yang juga meningkat selama pembelajaran daring (Farell et al., 2021).

4. Keterhubungan. Di awal disampaikan bahwa salah satu ciri pembelajaran daring yakni secara mandiri. Mandiri dalam belajar tetap ada komunikasi dengan siswa yang lain dan juga guru atau dosen secara online atau daring pula. Inilah yang dimaksud ada keterhubungan dalam pembelajaran daring. Dalam pelaksanaan proses pembelajaran tentu ada komunakasi terkait materi baik berupa diskusi, konsultasi atau komunikasi biasa dengan sesama teman. Jadi dengan konektivitas ini akan mendukung terjadinya proses pembelajaran yang interaktif dan tidak monoton atau diam. lebih luas lagi bisa dimaknai konektivitas ini mampu menjangkau orang atau sumber-sumber belajar yang lebih variatif tanpa terikat ruang dan waktu.

Dari ciri-ciri di atas bisa dipahami bahwa dengan pembelajaran daring proses belajar mengajar akan semakin fleksibel. Bisa diakses dan dilakukan dimana dan kapanpun saja. Beberapa keuntungan pembelajaran daring yakni efisien, bisa akses dimana dan kapan saja sesuai keinginan, terjangkau seperti tidak perlunya biaya transportasi dan jajan, kehadiran siswa meningkat karna mudah akses dimana dan kapanpun, terdapat variasi pilihan model dan gaya belajar (Gautam Priyanka, 2020). Pembelajaran ini tidak hanya memberikan kesempatan yang belum ada sebelumnya pada pelajar, tapi juga mengurangi biaya pendidikan yang cukup tinggi (Huong \& Giau, 2020). Dengan manajemen yang baik, sistem pembelajaran ini bisa berjalan sesuai harapan sebagaimana negara-negara maju. Sebaliknya jika tidak dengan persiapan yang matang, akan lebih banyak kerugian yang didapat dari pada nilai positif dari pembelajaran daring sebagimana dijelaskan Coman dkk. dalam penelitiannya di lembaga pendidikan tinggi Rumania sehingga pembelajaran daring (Coman et al., 2020). Namun dalam kondisi nyata di lapangan, terdapat beberapa kendala yang sangat signifikan dan mendasar dalam pembelajaran daring ini selama pandemi. Sebagaimana sering kali didapati peserta didik banyak siswa yang tidak aktif selama proses pembelajaran seperti kurang menyampaikan aspirasi dan pendapatnya sehingga yang dirasakan pembelajaran tersebut menjenuhkan dan tidak "hidup" sebagaimana tatap muka. Fakta ini juga selaras dengan penelitian yang dilakukan oleh Padma dan Sukanesh (2011) yang 
1467 Analisis Fenomena Pembelajaran Daring Pada Masa Pandemi (Harapan Menuju Blended Learning) Kutsiyyah

DOI: https://doi.org/10.31004/edukatif.v3i4.580

menyebutkan bahwa pembelajaran daring siswa cenderung tidak berperan aktif dalam pembelajaran, sehingga pembelajaran terasa membosankan dan menurunkan semangat dan minat belajar siswa (Kristina et al., 2020).

Fakta di atas menggambarkan bahwa pembelajaran daring tidak bisa secara penuh memenuhi kebutuhan dalam pendidikan. Ada banyak pengalaman yang bisa diambil dari pembelajaran tatap muka. Maka beberapa lembaga pendidikan juga mengambil model campuran untuk mendapat lebih banyak pengalaman dalam belajar. Blended learning represents a combination of face-to-face experiences and online learning experiences. Pengalaman dari pembelajaran daring dan tatap muka akan membantu menawarkan kesempatan untuk mencapai tujuan pendidikan lebih lanjut (Míguez-Álvarez et al., 2020).

Blended learning atau pembelajaran gabungan merupakan konsep pembelajaran yang menggabungkan antara pembelajaran online/daring dengan tatap muka. Model ini dapat dijadikan alternatif dan menjawab persoalan pembelajaran daring secara penuh (e-learning) yang tidak bisa menjangkau semua daerah dan beberapa aspek pendidikan yang tidak bisa disampaikan hanya dengan daring (Handoko \& Waskito, 2018). Selain Blended learning bisa menjadi jawaban dari kelemahan yang ada pada pembelajaran online, juga mampu menjadi solusi bagi pembelajaran tatap muka yang selalu terikat tempat dan waktu sehingga bisa menjadi lebih fleksibel dan menjangkau luas pengalaman belajar. Di sisi lain, ada hal signifikan dalam dunia pendidikan yang juga tidak bisa disampaikan secara daring, seperti nilai-nilai moral yang butuh role model dan juga praktikum yang butuh bimbingan, fasilitas dan kerja nyata.

Dari kelebihan yang dimiliki pembelajaran daring, seperti kemampuan mandiri dalam belajar siswa dan motivasi belajar yang tinggi akan mampu untuk memaksimalkan potensi siswa secara mandiri pula. Ini sesuai dengan temuan bahwa bahwa model pembelajaran Blended Learning efektif untuk meningkatkan kemandirian belajar peserta didik program paket C di Pusat Kegiatan Belajar Masyarakat (Sutisna, 2016). Namun demikian, karena masa pandemi masih berlangsung, maka pelaksanaan pembelajaran model ini harus memenuhi protokol kesehatan dan sesuai aturan yang berlaku sebagaimana Surat Keputusan Bersama Menteri Pendidikan dan Kebudayaan (Mendikbud), Menteri Agama (Menag), Menteri Kesehatan (Menkes), dan Menteri Dalam Negeri (Mendagri) tentang Panduan Penyelenggaraan Pembelajaran pada Tahun Ajaran 2020/2021 dan Tahun Akademik 2020/2021 di Masa Pandemi Coronavirus Disease 2019 (Covid-19) (Perkuliahan Dapat Dilakukan Secara Tatap Muka Dan Dalam Jaringan Tahun 2021, 2020). Maka kendala belajar daring yang bisa menurunkan kompetensi generasi peserta didik khususnya dalam memenuhi kebutuhan praktik dapat diatasi.

\section{KESIMPULAN}

Dari beberapa sumber literatur dan penelitian yang ada ditemukan bahwa pembelajaran daring merupakan kebiasaan baru yang sudah tidak asing dijumpai dalam dunia pendidikan. Dari jenjang pendidikan dasar hingga perguruan tinggi melaksana sistem pembelajaran daring/online. Ciri pembelajaran daring terdapat empat hal di dalamnya yakni Personal, Structured, Active dan Connective.

Dari ciri-ciri di atas bisa diambil kesimpulan bahwa pembelajaran daring merupakan alternatif terbaik untuk kegiatan pembelajaran pada masa pandemi. Hal ini karena pembelajaran daring bisa dilakukan dimana dan kapan saja. Media yang digunakan bisa bervariasi, namun aplikasi whatsapp merupakan salah satu media yang banyak dipilih dan digunakan untuk peroses pembelajaran baik di tingkat sekolah dasar bahkan di perguruan tinggi. Hal ini karena kemudahan dan kepraktisan media sosial tersebut yang disertai berbagai fitur pilihan yang mampu mengirim file, gambar, video, link, dan panggilan video. Media yang sangat familier di masyarakat ini menjadi pilihan favorit yang bisa membantu proses pembelajaran tetap berlangsung khususnya pada masa pandemi.

Kefleksibelan pembelajaran daring bukan berarti tanpa kendala. Karena berbasis internet dan menuntut kemandirian dalam belajar, maka kendalan fasilitas, kuota, jaringan yang sulit diakses, skil guru dan wali 
1468 Analisis Fenomena Pembelajaran Daring Pada Masa Pandemi (Harapan Menuju Blended Learning) Kutsiyyah

DOI: https://doi.org/10.31004/edukatif.v3i4.580

murid yang mendampingi belajar serta motivasi atau kemauan dari invidu juga tidak jarang menjadi kendala tersendiri bagi kegiatan pembelajaran daring untuk mencapai maksimal. Oleh karena itu, melihat kendala yang banyak dirasakan siswa, guru dan juga wali murid namun juga tidak menafinakan manfaat dan kelebihan pembelajaran daring, maka blended learning bisa jadi solusi. Hal ini juga bisa jadi peluang untuk penelitian selanjutnya untuk mengkaji lebih dalam tentang blended learning sebagai harapan baru dalam pendidikan di masa depan.

\section{DAFTAR PUSTAKA}

Abidah, A. (2020). Peran Aplikasi Whatsapp Sebagai Media Pembelajaran Dalam Mata Kuliah Metodologi Penelitian. Bidayah : Studi Ilmu-Ilmu Keislaman, 87. https://doi.org/10.47498/bidayah.v11i1.311

Anggianita, S., Yusnira, Y., \& Rizal, M. S. (2020). Persepsi Guru terhadap Pembelajaran Daring di Sekolah Dasar Negeri 013 Kumantan. Journal of Education Research. https://doi.org/10.37985/joe.v1i2.18

Asmuni, A. (2020). Problematika Pembelajaran Daring di Masa Pandemi Covid-19 dan Solusi Pemecahannya. Jurnal Paedagogy, 7(4), 281. https://doi.org/10.33394/jp.v7i4.2941

Coman, C., Țîru, L. G., Meseşan-Schmitz, L., Stanciu, C., \& Bularca, M. C. (2020). Online teaching and learning in higher education during the coronavirus pandemic: Students' perspective. Sustainability (Switzerland). https://doi.org/10.3390/su122410367

Ding, J., Hermawati, D., \&, \& Subakti, H. (2020). Analisis Media Pembelajaran Daring Di Era Pandemi Covid-19 Pada Kelas III SD Negeri 027 Samarinda Ulu. SISTEMA: Jurnal Pendidikan.

Farell, G., Simatupang, W., \& Giatman, M. (2021). EDUKATIF : JURNAL ILMU PENDIDIKAN Analisis Efektivitas Pembelajaran Daring pada SMK dengan Metode Asynchronous dan Synchronous. 3(4), 1185-1190.

Gautam Priyanka. (2020). Advantages And Disadvantages Of Online Learning - eLearning Industry. Https://Elearningindustry.Com/Advantages-and-Disadvantages-Online-Learning.

Handoko, H., \& Waskito, W. (2018). Blended Learning: Konsep dan Penerapannya. In Blended Learning: Konsep dan Penerapannya. https://doi.org/10.25077/car.64.60

Harahap, S. A., Dimyati, D., \& Purwanta, E. (2021). Problematika Pembelajaran Daring dan Luring Anak Usia Dini bagi Guru dan Orang tua di Masa Pandemi Covid 19. Jurnal Obsesi : Jurnal Pendidikan Anak Usia Dini. https://doi.org/10.31004/obsesi.v5i2.1013

Huong, P. T. T., \& Giau, T. T. N. (2020). The revolution in online learning and implication in Vietnamese universities. SOCIAL SCIENCES. https://doi.org/10.46223/hcmcoujs.soci.en.9.1.272.2019

Istikomah, I., Churahman, T., \& ... (2020). Problematika Wali Murid Sekolah Muhammadiyah dalam Mendampingi Belajar Daring di Masa Pandemi Covid-19. ... . Jurnal Pendidikan ....

Perkuliahan Dapat Dilakukan Secara Tatap Muka dan dalam Jaringan Tahun 2021, Https://Www.Kemdikbud.Go.Id (2020).

Kemdikbud. (2020). Pedoman Penyelenggaraan Belajar dari Rumah. Jakarta, 28 Mei 2020.

Khasanah, M. N., Ningrum, T., \& Aprilia, I. R. (2020). Analisis Kendala Mahasiswa Pendidikan Biologi Universitas Tidar Saat Pembelajaran Daring Di Masa Pandemi Covid-19. Nectar: Jurnal Pendidikan Biologi.

Khusaini, K., Suyudi, A., Winarto, W., \& Sugiyanto, S. (2017). Optimalisasi Penggunaan WhatsApp dalam Perkuliahan Penilaian Pendidikan Fisika. Jurnal Riset Dan Kajian Pendidikan Fisika, 4(1), 1. https://doi.org/10.12928/jrkpf.v4i1.6462

Kristina, M., Sari, R. N., \& Nagara, E. S. (2020). MODEL PELAKSANAAN PEMBELAJARAN DARING PADA MASA PANDEMI COVID 19 DI PROVINSI LAMPUNG. Idaarah: Jurnal Manajemen 
1469 Analisis Fenomena Pembelajaran Daring Pada Masa Pandemi (Harapan Menuju Blended Learning) Kutsiyyah

DOI: https://doi.org/10.31004/edukatif.v3i4.580

Pendidikan. https://doi.org/10.24252/idaarah.v4i2.16945

Kutsiyyah. (2019). Pembelajaran Akidah Akhlak (Moh. Muchlis Solichin (ed.); I). CV. Duta Media. javascript:void(0)

Lavasani, M. G., \& Faryadres, F. (2011). Language learning strategies and suggested model in adults processes of learning second language. Procedia - Social and Behavioral Sciences. https://doi.org/10.1016/j.sbspro.2011.03.072

Mendikbud RI. (2020). Surat Edaran Mendikbud RI Nomor 4 Tahun 2020 tentang Pelaksanaan Kebijakan Pendidikan dalam Masa Darurat Penyebaran Coronavirus Disease (COVID-19). Menteri Pendidikan Dan Kebudayaan Republik Indonesia.

Míguez-Álvarez, C., Crespo, B., Arce, E., Cuevas, M., \& Regueiro, A. (2020). Blending learning as an approach in teaching sustainability. Interactive Learning Environments. https://doi.org/10.1080/10494820.2020.1734623

Nina Nurmila, Maslani, Tarsono, L. S. (2020). Optimalisasi Pembelajaran Daring di UIN SGD Bandung dalam Upaya Menghentikan Penyebaran Virus Corona. Digital Library UIN Sunan Gunung Jati.

Rahmadi, D. (n.d.). Apa yang Harus Disiapkan Sekolah di Era Adaptasi Kebiasaan Baru? https://www.merdeka.com/peristiwa/apa-yang-harus-disiapkan-sekolah-di-era-adaptasi-kebiasaanbaru.html

Riyana, C. (2015). Konsep Pembelajaran Online. In Modul Pembelajaran Universitas Terbuka Tangerang Selatan.

Sugiyono. (2019). Metode Penelitian Pendidikan (Kuantitatif, Kualitatif, Kombinasi, R\&D dan Penelitian pendidikan ) (Apri Nuryanto (ed.); 3rd ed.). Penerbit Alfabeta.

Sutisna, A. (2016). Pengembangan Model Pembelajaran Blended Learning pada Pendidikan Kesetaraan Program Paket C dalam Meningkatkan Kemandirian Belajar. JTP - Jurnal Teknologi Pendidikan. https://doi.org/10.21009/jtp1803.2

Tasropi. (2020). memanfaatkan Whatsapp Untuk Pembelajaran Daring Pada Masa Pandemi.

Wahyugi, R., \& Fatmariza, F. (2021). Engembangan Multimedia Interaktif Menggunakan Software Macromedia Flash 8 Sebagai Upaya Meningkatkan Motivasi Belajar Siswa Sekolah Dasar. Edukatif: Jurnal Ilmu Pendidikan, 3(3), 791-800. 